\title{
The Progression of Esophageal Mucosa-associated Lymphoid Tissue Lymphoma after Helicobacter pylori Eradication Therapy: A Case Report and Discussion of Therapeutic Options
}

Yukari Takeuchi ${ }^{1}$, Koji Miyahara ${ }^{1}$, Toshiaki Morito ${ }^{2}$, Yoshiko Okikawa ${ }^{3}$, Hideaki Kinugasa ${ }^{1}$, Yuki Moritou ${ }^{1}$, Reiji Higashi ${ }^{1}$, Masaki Kunihiro ${ }^{1}$ and Masahiro Nakagawa ${ }^{4}$

\begin{abstract}
:
A 50-year-old woman with epigastric discomfort was referred to our hospital. Esophagogastroduodenoscopy showed flat, elevated, submucosal tumor-like lesions in the esophagus. Extranodal marginal zone lymphoma of the mucosa-associated lymphoid tissue (MALT lymphoma) of the esophagus was diagnosed based on the examination of an endoscopic biopsy specimen. Computed tomography showed the enlargement of a lymph node in the gastric cardia. The present case showed disease progression despite Helicobacter pylori eradication therapy and achieved partial remission after rituximab monotherapy. The patient remained in partial remission for 20 months. This case suggests that esophageal MALT lymphoma with lymph node involvement does not respond to $H$. pylori eradication therapy and that it requires systemic treatment.
\end{abstract}

Key words: eradication therapy, esophagus, Helicobacter pylori, MALT, rituximab

(Intern Med 58: 207-212, 2019)

(DOI: 10.2169/internalmedicine.1112-18)

\section{Introduction}

The gastrointestinal tract is the most commonly involved extranodal site in patients with non-Hodgkin lymphoma $(1,2)$. Within the gastrointestinal tract, malignant lymphoma most frequently occurs in the stomach; esophageal occurrence is observed in $<1 \%$ of patients with gastrointestinal lymphoma(2). Gastric mucosa-associated lymphoid tissue (MALT) lymphoma is well known to be associated with Helicobacter pylori $(\mathrm{Hp})$ infection, and $\mathrm{Hp}$ eradication is accepted as a first-line therapy for localized gastric MALT lymphoma (3). A few cases of patients with esophageal MALT lymphomas who achieved remission after $\mathrm{Hp}$ eradication therapy have been reported $(4,5)$. However, the efficacy of $H p$ eradication therapy has not been elucidated for patients with esophageal MALT lymphoma because there are few reports of patients who have undergone this treatment.
In this report, we describe the case of a patient with primary esophageal MALT lymphoma who had tumor enlargement after $H p$ eradication therapy and subsequently achieved partial remission (PR) with four cycles of rituximab.

\section{Case Report}

A 50-year-old woman with epigastric discomfort was referred to our hospital. Her pertinent medical history only included vasospastic angina, and she had no history of any autoimmune disease, alcohol abuse, or smoking.

Esophagogastroduodenoscopy (EGD) revealed flat, elevated, submucosal tumor-like lesions covered with a faded, smooth, normal mucosa in the upper, middle, and lower thoracic esophagus (Fig. 1A-C). The lesions discontinuously and craniocaudally extended anterior to the right wall and had an indistinct vascular pattern. Magnifying narrow-band imaging endoscopy revealed that the intrapapillary capillary loop on the surface of the lesions was normal; however, ab-

${ }^{1}$ Department of Internal Medicine, Hiroshima City Hospital, Japan, ${ }^{2}$ Department of Pathology, Hiroshima City Hospital, Japan, ${ }^{3}$ Department of Hematology, Hiroshima City Hospital, Japan and ${ }^{4}$ Department of Endoscopy, Hiroshima City Hospital, Japan Received: March 1, 2018; Accepted: May 21, 2018; Advance Publication by J-STAGE: August 24, 2018 Correspondence to Dr. Koji Miyahara, mkojisup@yahoo.co.jp 


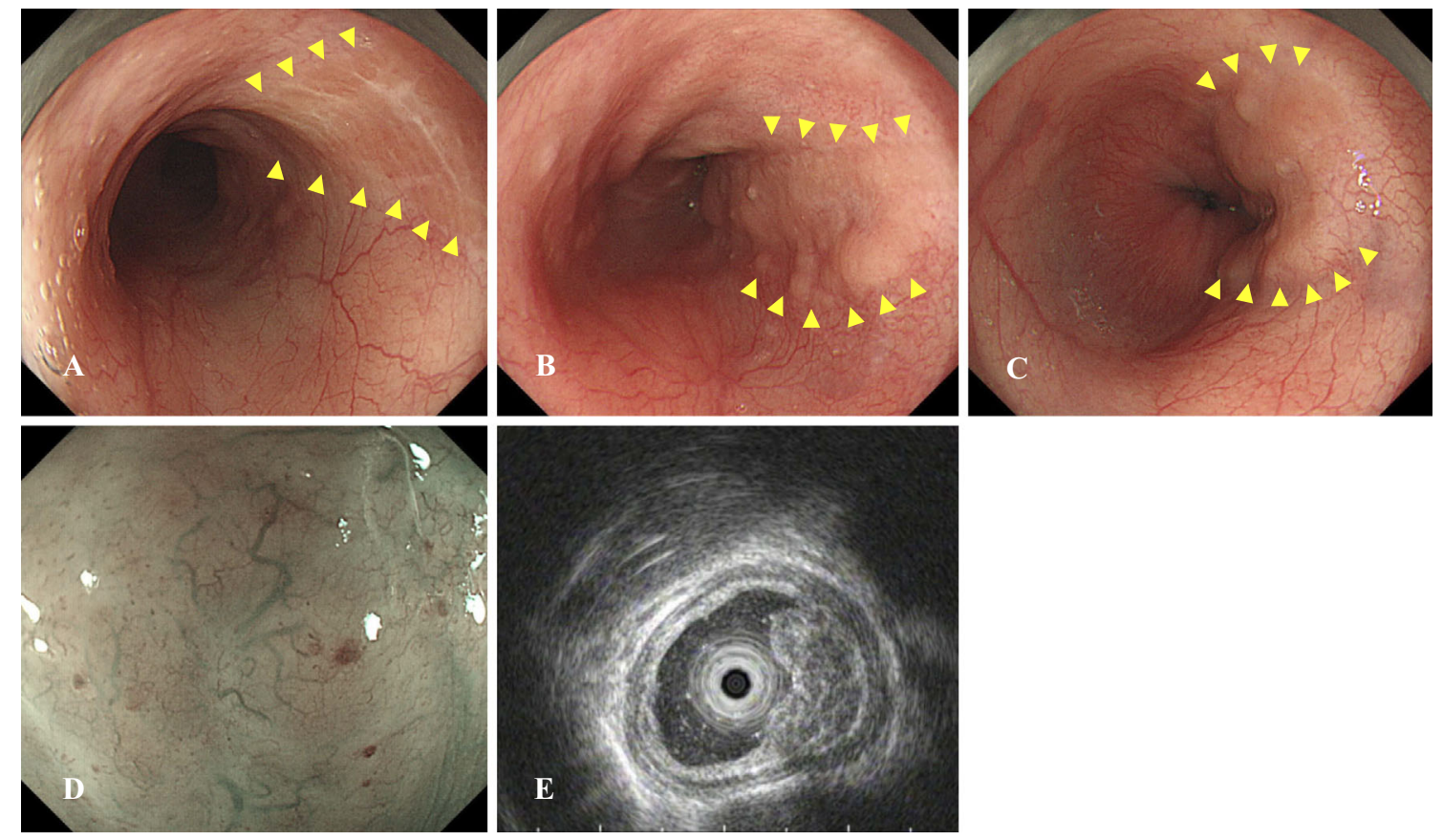

Figure 1. The endoscopic findings of the esophagus. Esophagogastroduodenoscopy revealed flat, elevated, submucosal tumor-like lesions covered with a smooth normal mucosa (arrowhead) in the upper (A), middle (B), and lower (C) thoracic esophagus. (D) Magnifying narrow-band imaging endoscopy showed abnormal blood vessels accompanied by vasodilation or tortuositas vasorum on the surface of the lesions in the lower thoracic esophagus. (E) Endoscopic ultrasonography showed a heterogeneous hypoechoic mass.
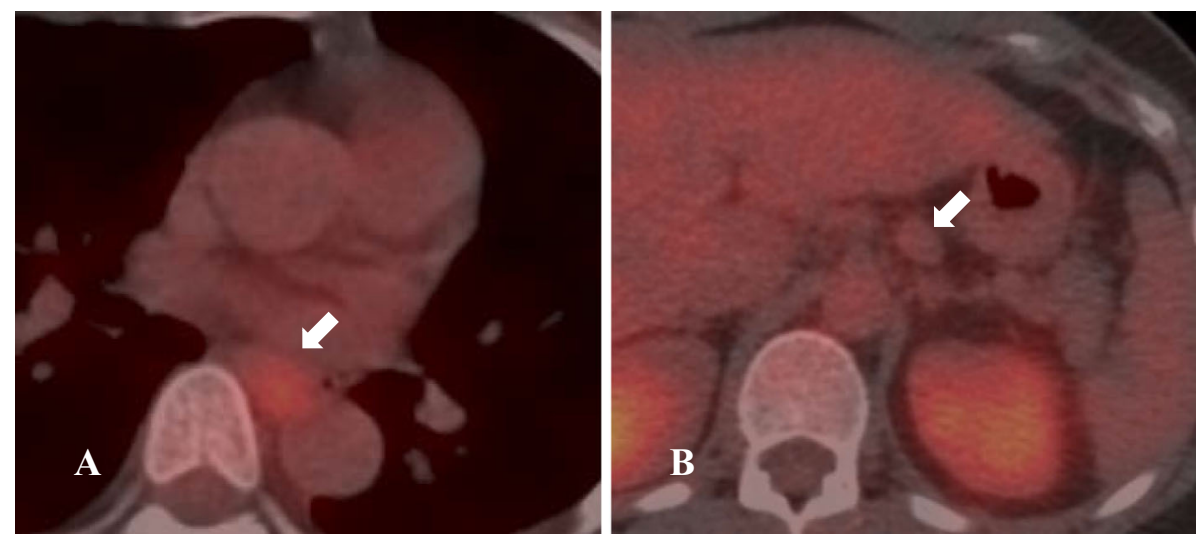

Figure 2. Positron emission tomography-computed tomography (PET-CT) of the lower esophagus (A) and a lymph node in the gastric cardia (B). (A) PET-CT demonstrated an increased ${ }^{18} \mathrm{~F}$-fluorodeoxyglucose (FDG) uptake in the esophagus (arrow). (B) Lymph node enlargement (15×10 mm) was observed without the significant accumulation of FDG (arrow).

normal blood vessels accompanied by vasodilation or tortuositas vasorum were recognized (Fig. 1D). Endoscopic ultrasonography showed a heterogeneous hypoechoic mass located in the submucosal layer (Fig. 1E). ${ }^{18} \mathrm{~F}-$ Fluorodeoxyglucose (FDG) positron emission tomographycomputed tomography demonstrated an increased FDG uptake in the middle and lower esophagus and enlargement of a lymph node in the gastric cardia $(15 \times 10 \mathrm{~mm})$ without FDG accumulation (Fig. 2). A histological examination of endoscopic biopsy specimens showed the aggregation of small or medium lymphoid cells. Immunohistochemistry revealed that they had a low Ki-67 index, were positive for CD20, and negative for CD5, CD10, and cyclin D1 (Fig. 3). Based on these findings, we diagnosed the patient with extranodal marginal zone lymphoma of the MALT of the esophagus with local nodal involvement.

The patient had closed-type atrophic gastritis and $H p$ infection was detected on a hematoxylin and eosin-stained specimen of the gastric mucosa. Furthermore, a rapid urease test was positive. Thus, the patient initially received $H p$ 

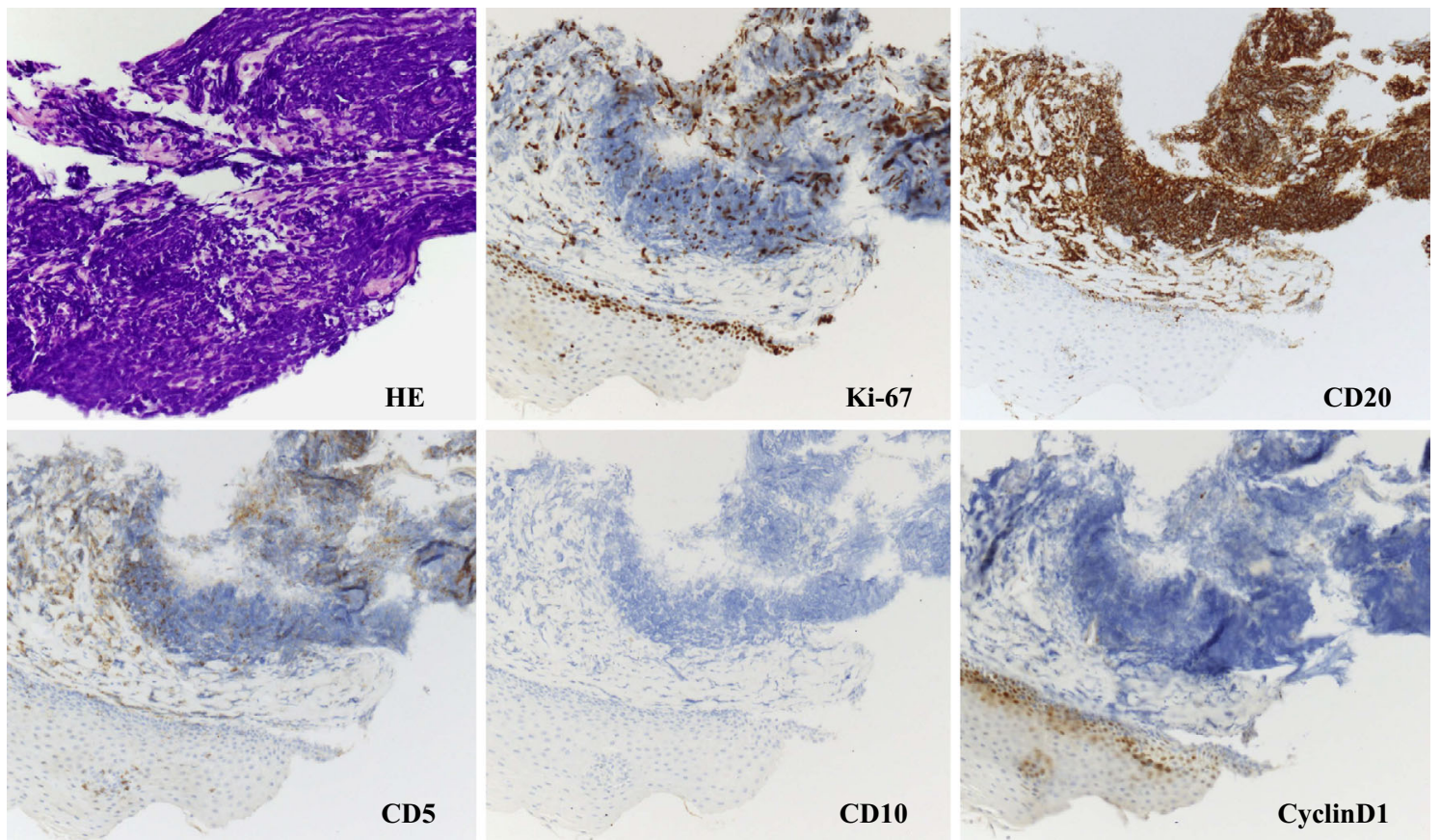

Figure 3. The histological examination of endoscopic biopsy specimens. The infiltration of small- or medium lymphoid cells was seen on a Hematoxylin and Eosin staining section (A: $\times 40)$. Immunohistochemistry revealed that the lymphoma cells had a low Ki-67 index $(\mathrm{B}: \times 10)$, were positive for CD20 (C: $\times 10)$, and negative for CD5 (D: ×10), CD10 (E: ×10), and cyclin D1 (F: ×10).
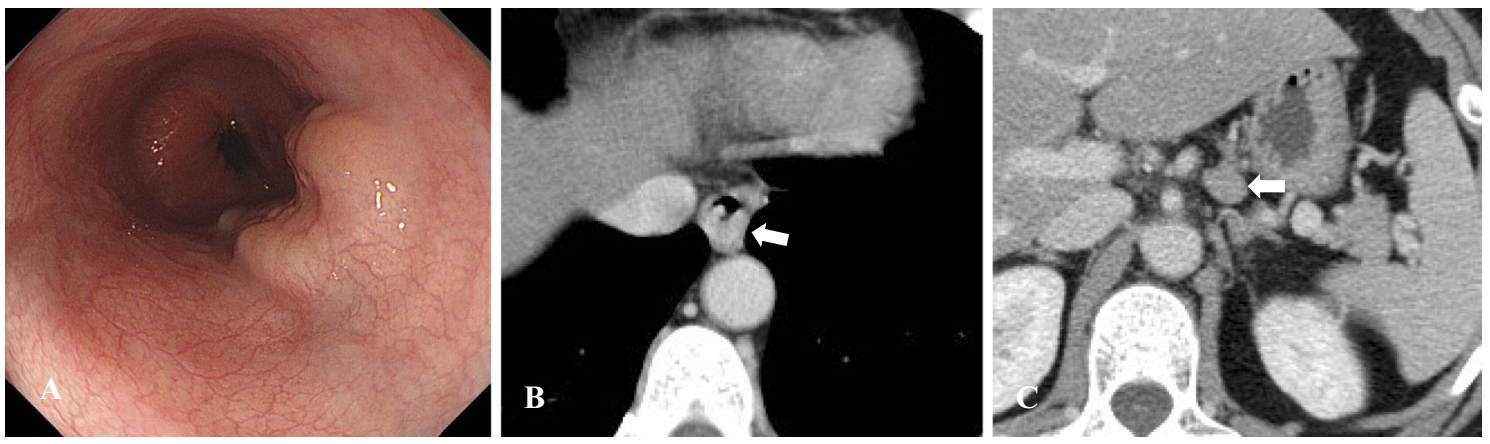

Figure 4. Esophagogastroduodenoscopy (EGD) and computed tomography (CT) images after Helicobacter pylori eradication. (A) EGD showed the enlargement of the esophageal lesions. (B) CT demonstrated a well-circumscribed enhancing mass in the lower thoracic esophagus (arrow). (C) The lymph node in the gastric cardia remained stable on CT $(15 \times 10 \mathrm{~mm})$ (arrow).

eradication therapy with vonoprazan (40 mg), amoxicillin $(1,500 \mathrm{mg})$, and clarithromycin $(800 \mathrm{mg})$ daily for 1 week. A ${ }^{13} \mathrm{C}$-urea breath test was negative at 5 weeks after eradication. However, EGD performed at 12 weeks after $\mathrm{Hp}$ eradication showed the enlargement of the esophageal lesions (Fig. 4). On computed tomography images, the esophageal lesion was demonstrated as a well-circumscribed enhancing mass (Fig. 4B), and the lymph node in the gastric cardia remained stable (Fig. 4C). The patient was subsequently treated with four cycles of rituximab $\left(375 \mathrm{mg} / \mathrm{m}^{2}\right)$ and achieved a PR with a reduction in the size of the esophageal lesions and lymph node (Fig. 5). A PR has been maintained for 20 months.

\section{Discussion}

Primary esophageal lymphoma is a rare tumor, and there only 25 case studies of MALT lymphoma in the esophagus have been reported to date $(4,5,6-28)$. In the previously reported cases, esophageal MALT lymphoma was treated with surgical resection (7-12), rituximab and/or chemotherapy $(12-19,27,28)$, radiotherapy $(8,12,20-22,28)$, endoscopic resection (20-26), and $H p$ eradication therapy (4, 5, $7,8,12,13,27)$; however, a standard treatment remains to be established.

The pathogenesis of MALT lymphoma is associated with chronic infection and inflammation (29). $H p$ infection is 

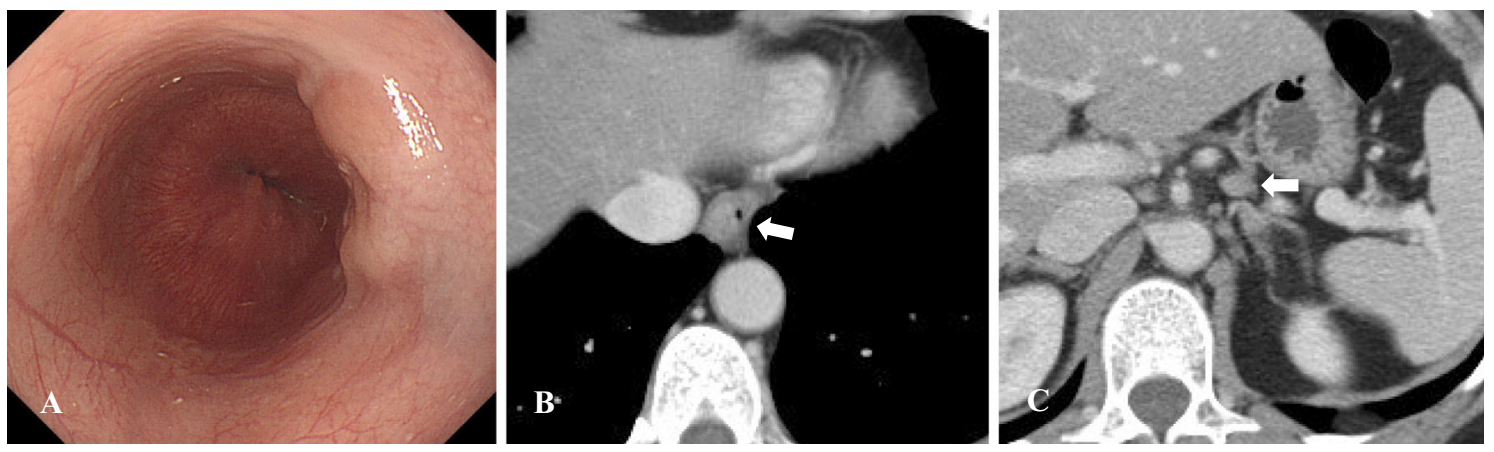

Figure 5. Esophagogastroduodenoscopy (EGD) and computed tomography (CT) images after four cycles of rituximab. (A) EGD showed a reduction in the size of the esophageal lesions. (B) CT demonstrated tumor shrinkage with a weak enhancement in the lower thoracic esophagus (arrow). (C) The lymph node in the gastric cardia was found to have decreased in size on CT $(11 \times 7 \mathrm{~mm})$ (arrow).

Table. Reported Cases of Esophageal Mucosa-associated Lymphoid Tissue Lymphoma with Helicobacter pylori (Hp) Eradication Therapy.

\begin{tabular}{|c|c|c|c|c|c|c|c|c|}
\hline No. & Age & Sex & $H p$ eradication therapy regimen & $\begin{array}{l}\text { Location } \\
\text { in the } \\
\text { esophagus }\end{array}$ & $\begin{array}{c}\text { Nodal } \\
\text { involvement }\end{array}$ & $\begin{array}{l}\text { Extranodal } \\
\text { involvement }\end{array}$ & $\begin{array}{l}\text { Clinical course after } \\
\text { eradication therapy }\end{array}$ & Reference \\
\hline 1 & 44 & M & $\begin{array}{l}\text { Lansoprazole } 60 \mathrm{mg} \text {, amoxicillin } \\
1,500 \mathrm{mg} \text {, and clarithromycin } 800 \mathrm{mg}\end{array}$ & Lower & None & None & $\begin{array}{l}\text { Complete remission } \\
\text { No recurrence for } \\
1 \text { year }\end{array}$ & 5 \\
\hline 2 & 76 & $\mathrm{~F}$ & $\begin{array}{l}\text { 1st: lansoprazole } 60 \mathrm{mg} \text {, amoxicillin } \\
1,500 \mathrm{mg} \text {, and clarithromycin } 400 \mathrm{mg} \\
\text { 2nd: lansoprazole } 60 \mathrm{mg} \text {, amoxicillin } \\
1,500 \mathrm{mg} \text {, and metronidazole } 500 \mathrm{mg}\end{array}$ & Lower & None & None & $\begin{array}{l}\text { Complete remission } \\
\text { No recurrence for } \\
3 \text { years }\end{array}$ & 4 \\
\hline 3 & 61 & M & $\begin{array}{l}\text { 1st: metronidazole, tetracycline, } \\
\text { bismuth subsalicylate, and ranitidine } \\
\text { 2nd: clarithromycin and lansoprazole } \\
\text { (Dosages were not described) }\end{array}$ & Proximal & None & None & Not described & 27 \\
\hline 4 & 70 & M & Not described & Upper & $\begin{array}{l}\text { Mediastinal } \\
\text { lymph } \\
\text { nodes }\end{array}$ & None & $\begin{array}{l}\text { Not described } \\
\text { (Partial remission } \\
\text { after rituximab) }\end{array}$ & 13 \\
\hline 5 & 50 & $\mathrm{~F}$ & $\begin{array}{l}\text { Vonoprazan } 40 \mathrm{mg} \text {, amoxicillin } 1,500 \\
\mathrm{mg} \text {, and clarithromycin } 800 \mathrm{mg}\end{array}$ & $\begin{array}{l}\text { Upper, } \\
\text { middle, } \\
\text { and lower }\end{array}$ & $\begin{array}{c}\text { Gastric } \\
\text { cardia } \\
\text { lymph node }\end{array}$ & None & $\begin{array}{l}\text { Progressive disease } \\
\text { (Partial remission } \\
\text { after rituximab) }\end{array}$ & $\begin{array}{l}\text { (Present } \\
\text { case) }\end{array}$ \\
\hline
\end{tabular}

found in $50-100 \%$ of patients with gastric MALT lymphoma (30), and $60-90 \%$ of patients with gastric MALT lymphoma achieve complete remission (CR) after $H p$ eradication (31). In the clinical practice guidelines, $\mathrm{Hp}$ eradication therapy is described as a first choice for treating localized gastric MALT lymphoma $(32,33)$. However, the association between esophageal MALT lymphoma and $H p$ infection remains controversial. Four cases in which $\mathrm{Hp}$ eradication therapy was administered for esophageal MALT lymphoma have been reported (Table); two patients with localized disease achieved a $\mathrm{CR}$ after $H p$ eradication therapy $(4,5)$, whereas another case with lymph node involvement was treated with $H p$ eradication followed by rituximab (13). The other case had MALT lymphoma in the esophagus and stomach and required chemotherapy after $\mathrm{Hp}$ eradication (27). In the present case, tumor progression was observed during a relatively short period (12 weeks) after $H p$ eradication. These results indicate that $H p$ eradication may be effective for treating esophageal MALT lymphoma confined to the gastrointestinal tract, whereas esophageal MALT lymphoma involving the lymph nodes or other organs requires systemic chemotherapy and/or rituximab. Consequently, we recommend close follow-up [e.g., EGD with multiple biopsies 2-3 months after $H p$ eradication (3)], for patients with esophageal MALT lymphoma and additional treatments should be considered for patients with progressive disease.

Although tumor regression is sometimes recognized after $H p$ eradication therapy for non-gastric MALT lymphoma $(4,5,34-37)$, the mechanism has remained to be elucidated. The regression of colorectal MALT lymphoma after the administration of drugs used for $\mathrm{Hp}$ eradication has been reported, even in patients who were negative for $\mathrm{Hp}$ infection $(35,37)$, suggesting that unknown, antibiotic-sensitive microorganisms (other than $\mathrm{Hp}$ ) are involved in the development of non-gastric MALT lymphoma. However, further investigation is required to reveal the mechanisms underlying the effects of $H p$ eradication therapy and its efficacy in pa- 
tients with non-gastric MALT lymphoma. In addition, there is no evidence to support eradication therapy in cases with extranodal involvement; thus, the immediate start of oncological treatment should be considered if no signs of regression are seen in such patients.

With regard to the treatment options for non-gastric MALT lymphoma (all stages), chemotherapy, immunotherapy, or a combination of both was suggested by the European Society for Medical Oncology (ESMO) consensus conferences (33). Radiotherapy was only considered to be a reasonable option for localized lymphomas (33). However, no definitive evidence has been found in favor of any of these modalities in the treatment of localized non-gastric MALT lymphoma. In addition, there is no standard chemotherapy regimen. There are seven reported cases of rituximab and/or chemotherapy being administered to patients with esophageal MALT lymphoma. In one case, a PR was achieved in a patient treated with rituximab monotherapy after $H p$ eradication (13); this was similar to the outcome in the present case. A CR was achieved in a patient treated with cyclophosphamide, vincristine, and prednisone (CVP) therapy (14), while a PR was achieved in a patient treated with cyclophosphamide, doxorubicin, vincristine, and prednisone (CHOP) therapy (18). Two of the four patients treated with rituximab-combined $\mathrm{CHOP}$ (R-CHOP) therapy achieved a CR (15-17, 19). From these results, chemotherapy with and without rituximab might be more effective for achieving a CR. However, rituximab monotherapy might be a feasible option for disease control in patients with non-progressive MALT lymphoma because it is not necessary to achieve a CR in such cases (23).

Esophageal MALT lymphoma is a rare tumor and may be difficult to diagnose at an early stage. Oğuzkurt et al. reported that the radiological findings of esophageal lymphoma may vary, but that the following characteristics may lead radiologists to suspect lymphomatous involvement: (i) thickened mucosal folds, (ii) submucosal nodules accompanying a tumoral mass, (iii) multiple craters and erosions, and (iv) a tumoral mass without narrowing or stricture formation (38). In a recent report that reviewed 14 patients with esophageal MALT lymphoma, the endoscopic findings of 11 patients showed submucosal tumor-like lesions; nine of these had craniocaudal extension (22). The present case showed both of these endoscopic findings, and we additionally observed the presence of abnormal blood vessels similar to a tree-like appearance, which is a typical characteristic of gastric lesions in MALT lymphoma $(39,40)$. This characteristic was recently reported in an esophageal lesion by Kudo et al. (25). These radiological and endoscopic characteristics may be helpful in detecting esophageal MALT lymphoma lesions, and should prompt endoscopists to perform a biopsy to obtain specimens for histological examination.

Taken together, the patient in the present case showed disease progression of esophageal MALT lymphoma after $H p$ eradication therapy and achieved a PR after the initiation of rituximab monotherapy, indicating that close follow-up is preferable, even after $H p$ eradication therapy, because responses may vary among patients.

The authors state that they have no Conflict of Interest (COI).

\section{References}

1. Amer MH, El-Akkad S. Gastrointestinal lymphoma in adults: clinical features and management of 300 cases. Gastroenterology 106: 846-858, 1994.

2. Herrmann R, Panahon A, Barcos MP, Walsh D, Stutzman L. Gastrointestinal involvement in non-Hodgkin's lymphoma. Cancer 46: 215-222, 1980.

3. Zucca E, Copie-Bergman C, Ricardi U, Thieblemont C, Raderer M, Ladetto M. Gastric marginal zone lymphoma of MALT type: ESMO Clinical Practice Guidelines for diagnosis, treatment and follow-up. Ann Oncol 24: 144-148, 2013.

4. Moriya K, Tamura H, Nakamura K, Hosone M, Inokuchi K. A primary esophageal MALT lymphoma patient with Helicobacter pylori infection achieved complete remission after $H$. pylori eradication without anti-lymphoma treatment. Leuk Res Rep 7: 2-5, 2017.

5. Sawada K, Ikuta K, Itabashi K, et al. An unusual elevated lesion of the oesophagus. Gut 60: 441-516, 2011.

6. Nishiyama Y, Yamamoto Y, Ono Y, et al. Visualization of esophageal non-Hodgkin's lymphoma with Ga-67 scintigraphy. Ann Nucl Med 13: 419-421, 1999.

7. Shim CS, Lee JS, Kim JO, et al. A case of primary esophageal Bcell lymphoma of MALT type, presenting as a submucosal tumor. J Korean Med Sci 18: 120-124, 2003.

8. Jung JG, Kang HW, Hahn SJ, Choi JS, Kim EJ. Primary mucosaassociated lymphoid tissue lymphoma of the esophagus, manifesting as a submucosal tumor. Korean J Gastroenterol 62: 117-121, 2013.

9. Bardisi ES, Alghanmi N, Merdad AA. Primary mucosa-associated lymphoid tissue lymphoma of the esophagus masquerading as a benign tumor. Ann Med Surg (Lond) 3: 39-42, 2014.

10. Ma Q, Zhang C, Fang S, et al. Primary esophageal mucosaassociated lymphoid tissue lymphoma: a case report and review of literature. Medicine (Baltimore) 96: 6478, 2017.

11. Miyazaki T, Kato H, Masuda N, et al. Mucosa-associated lymphoid tissue lymphoma of the esophagus: case report and review of the literature. Hepatogastroenterology 51: 750-753, 2004.

12. Byun SJ, Kang HW, Cha JK, et al. Primary mucosa-associated lymphoid tissue lymphoma metachronously involving esophagus and stomach. Korean J Gastroenterol 67: 257-261, 2016.

13. Tsujii $Y$, Nishida $T$, Kato $M$, et al. Mucosa-associated lymphoid tissue (MALT) lymphoma of the esophagus. Dis Esophagus 26: 349-350, 2013.

14. Lee DS, Ahn YC, Eom DW, Lee SJ. Primary esophageal mucosaassociated lymphoid tissue lymphoma diagnosed by using stacked forceps biopsy. Dis Esophagus 29: 887-890, 2016.

15. Musquer N, Zidane-Marinnes M, Dib M. Primary mucosaassociated lymphoid tissue lymphoma of the entire esophagus. Gastrointest Endosc 86: 560-561, 2017.

16. Ogura T, Tajika M, Hijioka S, et al. First report of a mucosaassociated lymphoid tissue (MALT) lymphoma of the esophagus diagnosed by endoscopic ultrasound-guided fine-needle aspiration (EUS-FNA). Endoscopy 44: 167-168, 2012.

17. Ishida M, Hodohara K, Furuya A, et al. Sarcoidal granulomas in the mediastinal lymph nodes after treatment for marginal zone lymphoma of the esophagus: report of a case with review of the concept of the sarcoidosis-lymphoma syndrome. Int J Clin Exp Pathol 7: 4428-4432, 2014.

18. Chung JJ, Kim MJ, Kie JH, Kim KW. Mucosa-associated lym- 
phoid tissue lymphoma of the esophagus coexistent with bronchus-associated lymphoid tissue lymphoma of the lung. Yonsei Med J 46: 562-566, 2005.

19. Hayashi M, Ueda K, Tanaka T, et al. Mucosa-associated lymphoid tissue (MALT) lymphoma arising in the esophagus, stomach, and lung. Gen Thorac Cardiovasc Surg 59: 826-830, 2011.

20. Kitamoto $Y$, Hasegawa M, Ishikawa $H$, et al. Mucosa-associated lymphoid tissue lymphoma of the esophagus: a case report. J Clin Gastroenterol 36: 414-416, 2003.

21. Yano S, Usui N, Dobashi N, et al. A case of primary esophageal mucosa-associated lymphoid tissue lymphoma with a numerical abnormality of $18 \mathrm{q} 21$ detected by fluorescence in situ hybridization. Ann Hematol 88: 703-704, 2009.

22. Kishi K, Maeda H, Nakamura Y, Shirai S, Sato M. Radiotherapy for mucosa-associated lymphoid tissue (MALT) lymphoma of the esophagus: a case report with a diagnostic and therapeutic discussion. Int J Clin Oncol 17: 174-180, 2012.

23. Hosaka S, Nakamura N, Akamatsu T, et al. A case of primary low grade mucosa associated lymphoid tissue (MALT) lymphoma of the oesophagus. Gut 51: 281-284, 2002.

24. Baek DH, Kim GH, Song GA, et al. Primary esophageal mucosaassociated lymphoid tissue lymphoma treated with endoscopic resection. Gastrointest Endosc 75: 1282-1283, 2012.

25. Kudo K, Ota M, Narumiya K, Shirai Y, Ohki T, Yamamoto M. Primary esophageal mucosa-associated lymphoid tissue lymphoma treated by endoscopic submucosal dissection. Dig Endosc 26: 478481, 2014.

26. Ling T, Min H, Zou X. A rare esophageal neoplasm. Gastroenterology 147: e8-e9, 2014.

27. Soweid AM, Zachary PE Jr. Mucosa-associated lymphoid tissue lymphoma of the oesophagus. Lancet 348: 268-269, 1996.

28. Malik AO, Baig Z, Ahmed A, Qureshi N, Malik FN. Extremely rare case of primary esophageal mucous associated lymphoid tissue lymphoma. World J Gastrointest Endosc 5: 446-449, 2013.

29. Guidoboni M, Ferreri AJ, Ponzoni M, Doglioni C, Dolcetti R. Infectious agents in mucosa-associated lymphoid tissue-type lymphomas: pathogenic role and therapeutic perspectives. Clin Lymphoma Myeloma Leuk 6: 289-300, 2006.

30. Asenjo LM, Gisbert JP. Prevalence of Helicobacter pylori infection in gastric MALT lymphoma: a systematic review. Rev Esp Enferm Dig 99: 398-404, 2007.

31. Nakamura S, Matsumoto T. Treatment strategy for gastric mucosa- associated lymphoid tissue lymphoma. Gastroenterol Clin North Am 44: 649-660, 2015.

32. NCCN Clinical Practice Guidelines in Oncology (NCCN Guidelines ${ }^{\mathbb{B}}$ ) B-cell Lymphomas Version 2.2017-February 21, 2017. [Internet]. [cited 2017 Nov. 21]. Available from: http://oncolife.com.u a/doc/nccn/B-Cell_Lymphomas.pdf

33. Dreyling M, Thieblemont C, Gallamini A, et al. ESMO Consensus Conferences: guidelines on malignant lymphoma. Part 2: Marginal zone lymphoma, mantle cell lymphoma, peripheral T-cell lymphoma. Ann Oncol 24: 857-877, 2013.

34. Matsumoto T, Iida M, Shimizu M. Regression of mucosaassociated lymphoid-tissue lymphoma of rectum after eradication of Helicobacter pylori. Lancet 350: 115-116, 1997.

35. Inoue F, Chiba T. Regression of MALT lymphoma of the rectum after anti-H. pylori therapy in a patient negative for $H$. pylori. Gastroenterology 117: 514-515, 1999.

36. Raderer M, Pfeffel F, Pohl G, Mannhalter C, Valencak J, Chott A. Regression of colonic low grade B cell lymphoma of the mucosa associated lymphoid tissue type after eradication of Helicobacter pylori. Gut 46: 133-135, 2000.

37. Nakase H, Okazaki K, Ohana M, et al. The possible involvement of micro-organisms other than Helicobacter pylori in the development of rectal MALT lymphoma in $H$. pylori-negative patients. Endoscopy 34: 343-346, 2002.

38. Oğuzkurt L, Karabulut N, Cakmakci E, Besim A. Primary nonHodgkin's lymphoma of the esophagus. Abdom Imaging 22: 8-10, 1997.

39. Nonaka K, Ishikawa K, Shimizu M, et al. Education and imaging. Gastrointestinal: gastric mucosa-associated lymphoma presented with unique vascular features on magnified endoscopy combined with narrow-band imaging. J Gastroenterol Hepatol 24: 1697, 2009.

40. Ono S, Kato M, Ono Y, et al. Characteristics of magnified endoscopic images of gastric extranodal marginal zone B-cell lymphoma of the mucosa-associated lymphoid tissue, including changes after treatment. Gastrointest Endosc 68: 624-631, 2008.

The Internal Medicine is an Open Access journal distributed under the Creative Commons Attribution-NonCommercial-NoDerivatives 4.0 International License. To view the details of this license, please visit (https://creativecommons.org/licenses/ by-nc-nd/4.0/).

(C) 2019 The Japanese Society of Internal Medicine Intern Med 58: 207-212, 2019 